\title{
Induction of Hepatic Drug Metabolizing Enzymes and Mutagen-activation Capacity in Several Animal Species
}

\author{
Hiroshi Suzuki, Fumio Kishida and Junshi Miyamoto \\ Research Department, Pesticides Division, Sumitomo Chemical Co., Ltd., \\ Takarazuka, Hyogo 665, Japan
}

(Received April 19, 1977)

\begin{abstract}
To improve Ames' chemical carcinogen screening test system, several species of animals including rats, mice, guinea pigs, hamsters and rabbits were pre-treated with polychlorinated biphenyl (PCB), 3-methylchoranthrene (MC) and phenobarbital $(\mathrm{PB})$, and hepatic S-9 fraction obtained therefrom was tested as to the effects on the increase of revertant colonies of S. typhimurium TA98 and TA100. Among 12 strains of the 5 mammalian species, S-9 fraction from PCB-treated Hartley guinea pig proved to be more effective than that from PCB-treated SD rat in detecting three different types of mutagens, Benzo(a)pyrene, 2-acetylaminofluorene and dimethylnitrosamine. The methylcholanthrene-pretreated guinea pig (Hartley) liver S-9 was equally effective to the rat preparation and PCB-treated hamster S-9 fractions were effective to DMN mutagenesis, whereas Wistar and Fisher rats, ICR and dd mice and rabbits were generally no better than SD rat.
\end{abstract}

\section{INTRODUCTION}

One of the detection methods for mutagenicity and carcinogenicity of environmental chemicals including pesticides has been developed by Ames et al. ${ }^{1,2)}$ which utilizes several strains of Salmonella typhimurium combined with in vitro drug metabolizing enzyme systems (S-9) from rat liver. Although Sprague Dawley rats have been often used as the metabolizing enzyme source ${ }^{1,2)}$ in such trails, S-9 fractions of other mammalian species might be better, since metabolic pathways of a compound as well as its carcinogenic potential are varied with mammalian species. The mouse and other species were used in some cases, ${ }^{3,4)}$ but any attempts have hardly been made so far to compare the capacity of hepatic preparations obtained from various mammalian species including rabbits, guinea pigs and hamsters. Therefore, studies were initiated to select the most pertinent mammalian species for preparation of S-9 fraction among rats, mice, rabbits, guinea pigs and hamsters, after pre-treatment with 3 different types of inducers of drug metabolizing enzymes, polychlorinated biphenyl (PCB), phenobarbital (PB) and 3-methylcholanthrene (MC).

\section{MATERIALS AND METHODS}

\section{Special Chemicals}

Benzo(a)pyrene (BaP), 2-acethylaminofluorene $(\mathrm{AAF})$, dimethylnitrosamine $(\mathrm{DMN})$ and 3-methylcholanthrene (MC) were obtained from Wako Pure Chemical (Osaka). Sodium phenobarbital (PB) and NADPH were purchased from Fuzinaga Chemical (Tokyo) and Oriental Yeast (Osaka), respectively. Polychlorinated biphenyl (PCB, Kanechlor 400) was kindly supplied by Prof. N. Ito of Nagoya City University Medical school.

\section{Animals}

The following animals species were used in the present experiment; 5 week old Spraque Dawley (SD) (male and female), Fisher (male) and Wistar (male) rats weighing 160-200 g; 6-week-old male ICR and dd mice, 20-30 g; 
5-week-old male Golden (80-100 g) and Chinese (20-30 g) hamsters; 6-week-old male Hartley and hybrid guinea pigs, $350-400 \mathrm{~g}$; 10-weekold male New Zealand White rabbits and Japanese native strain rabbits, $1.9-2.3 \mathrm{~kg}$. Rats and mice were obtained from Nihon Clea (Osaka), and other animal species, from Nihon Dobutsu (Osaka).

\section{Bacteria}

Salmonella typhimurium TA98 and TA1005) were supplied by Dr. B. N. Ames, University of California.

\section{Pre-treatment of the Animals with $P C B$, $M C$ and $P B$}

$\mathrm{PCB}$ and $\mathrm{MC}$ were dissolved in corn oil $(10 \%)$ and administered once to the animals intraperitoneally at 0 -day. The administered level of PCB was $500 \mathrm{mg} / \mathrm{kg}$ for all animals, and $\mathrm{MC}$ was given at the rate of $80 \mathrm{mg} / \mathrm{kg}$ to rats, mice, hamsters and guinea pigs, and 50 $\mathrm{mg} / \mathrm{kg}$ to rabbits. $\mathrm{PB}$ was dissolved in physiological saline $(10 \%)$ and given intraperitoneally once a day for five days. The dose levels were $80 \mathrm{mg} / \mathrm{kg} /$ day for rats, mice, and hamsters, $50 \mathrm{mg} / \mathrm{kg} /$ day for rabbits, and $40 \mathrm{mg} / \mathrm{kg} /$ day for guinea pigs.

\section{5. $S-9$}

The hepatic S-9 fraction of each animal species was prepared by the method described by Ames et al. ${ }^{2)}$

\section{Mutation Test}

The mutagenic potentials of $\mathrm{BaP}, \mathrm{AAF}$ and DMN were tested on $S$. typhimurium TA98 and TA100 in the presence of S-9 fraction, according to the procedures reported elsewhere, ${ }^{6}$ ) which were essentially the same as Ames' method. ${ }^{1,2)}$ The number of spontaneous revertant colonies was $15-40 /$ plate in TA98 and 80-160/plate in TA100 after $48 \mathrm{hr}$ incubation at $37^{\circ} \mathrm{C}$.

\section{Measurement of Cytochrome P-450 Content}

The contents of cytochrome P-450 (P-450) in S-9 fraction were measured according to the methods described by Ohmura and Sato. ${ }^{7)}$
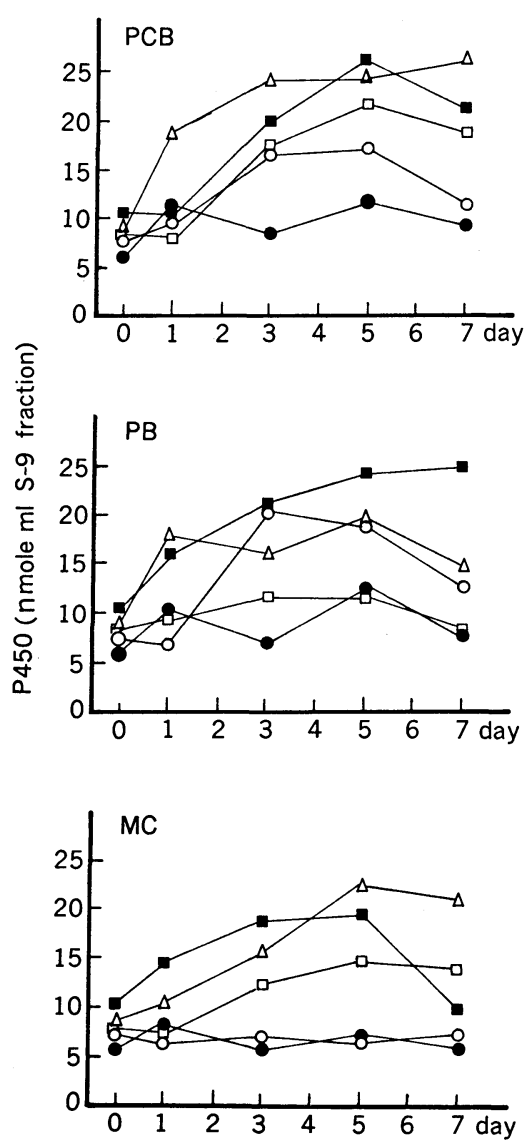

Fig. 1 Cytochrome P-450 contents in hepatic S-9 from several animal species after administration of $\mathrm{PCB}, \mathrm{PB}$ or $\mathrm{MC}$.

O rat, - mouse, $\square$ guinea pig, $\square$ rabbit $\triangle$ hamster

\section{RESULTS AND DISCUSSIONS}

The drug metabolizing capacities of S-9 fraction are known to depend to some degrees on the quantity of P-450, so, the levels of hepatic P-450 in S-9 fraction were measured in $\mathrm{SD}$ rats, ICR mice, Golden hamsters, Hartley guinea pigs and New Zealand White rabbits after intraperitoneal application of the three inducers. Figure 1 presents the results. In PCB-treated animals, P-450 contents increased in all species and the maximum levels were observed on 5th day after PCB treatment, 1.8-2.9 times higher than the controls. By consecutive treatment with $\mathrm{PB}, \mathrm{P}-450$ increased 
in all animals during the administration, which, however, tended to decrease on cessation of PB treatment. The maximum levels were 2-3 times higher than the controls. MC treatment did not affect P-450 levels rats and mice during the subsequent 7 days, while in hamsters, guinea pigs and rabbits P-450 levels increased and reached maximum on 5th day after administration.

To confirm the correlation of P-450 levels with mutation-inducing capacities, S-9 fraction prepared from SD rats was used for mutation test with $\mathrm{BaP}, \mathrm{AAF}$ or DMN. Although the data are not presented here, the number of mutants caused by Bap, AAF and DMN was increased by PCB-treatment and the maximum was observed with S-9 prepared at 3 to 5 days after treatment. By PB-treated S-9, only AAF increased mutation, and the fraction obtained at 5 days post-treatment was most effective.

On the 3rd to 5 th day after MC-treatment the S-9 fraction increased the mutation by $\mathrm{BaP}$ and $\mathrm{AAF}$ appreciably, in contrast to the unaltered content of P-450 in rats and mice. DMN-induced mutation was not affected.

Thus, roughly, the higher P-450 contents reflected the increased number of the mutants. Based on the above experiments, effects of the inducers on mutagen-activating capacities of S-9 fraction were tested by sacrificing the animals at 5 days after the treatments. The animals pre-treated with MC were also sacrificed after $24 \mathrm{hr}$, as is usually the case. ${ }^{1)}$ The effects on reverse mutations of S-9 fraction obtained from the liver of various animal species pre-treated with $\mathrm{PCB}, \mathrm{PB}$ or $\mathrm{MC}$ are collectively summarized in Table 1. All the examinations were carried out at three or more concentrations of the mutagens, replicated at least three times, as typical examples are given in Fig. 2. However, to facilitate the comparison, the data with one concentration are presented in Table 1 , namely BaP $10 \mu \mathrm{g} /$ plate, AAF $80 \mu \mathrm{g} /$ plate and DMN 3,000 $\mu \mathrm{g} /$ plate. As DMN did not substantially induce reverse mutation in the TA98 strain in the presence of S-9 of any mammalian species, the results are not included in the Table.

As evident in Table 1, generally two strains of mice, Fisher, Wister rats were no better
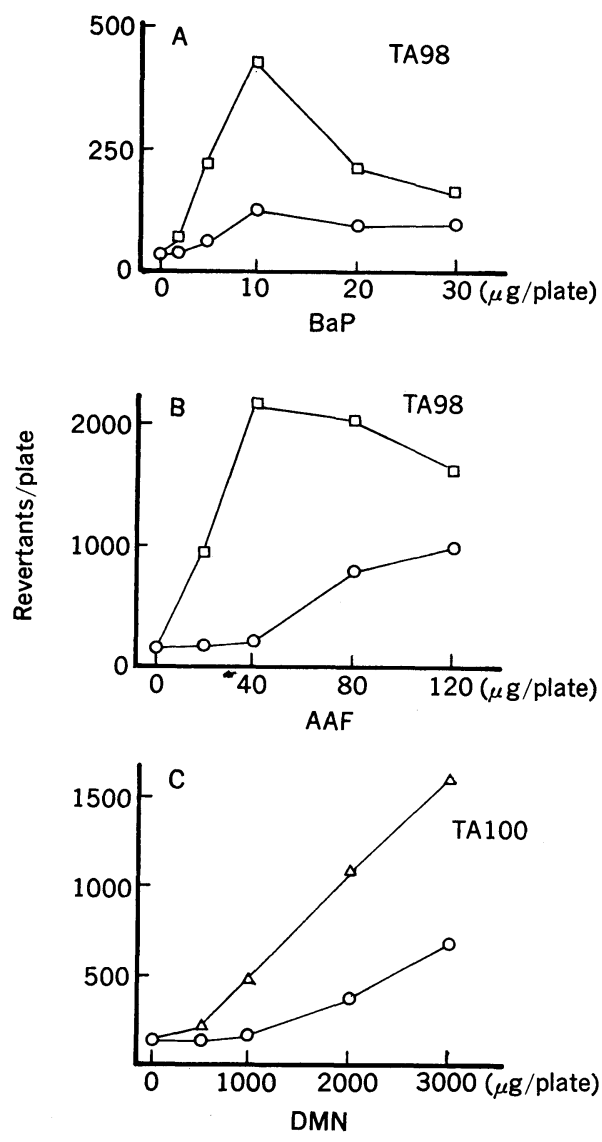

Fig. 2 Increase of $S$. typhimurium reverse mutants in the presence of S-9 fractions obtained from several animal species pretreated with inducers.

A) Mutants of TA98 strain by BaP in the presence of PCB-treated SD rat and PCBtreated Hartley guinea pig S-9.

B) Mutants of TA98 strain by AAF in the presence of PB-treated guinea pig and PCB-treated SD rat S-9.

C) Mutants of TA100 strain by DMN in the presence of PCB-treated Golden hamster and $\mathrm{PCB}$-treated $\mathrm{SD}$ rat S-9.

$\square$ PCB-Hartley guinea pig, $\bigcirc$ PCB-SD rat, $\triangle$ PCB-Golden hamster.

than SD rats, and male SD rats were better than the females. Some of the non-treated (control) animal species, especially guinea pigs, rabbits and hamsters gave the same levels of mutants as, or in some cases higher than, PCBtreated SD rat. Among the three inducers, $\mathrm{PCB}$ was generally most effective in increasing 
Table 1 Number of mutants of S. typhimurium TA 98 and TA100 caused by BaP, $\mathrm{AAF}$, or DMN combined with $\mathrm{S}-9$ fractions obtained from inducer-treated animals species.

\begin{tabular}{|c|c|c|c|c|c|c|c|}
\hline \multirow{3}{*}{$\begin{array}{l}\text { Animal } \\
\text { species }\end{array}$} & \multirow{3}{*}{ Strains } & \multirow{3}{*}{ Inducers } & \multicolumn{5}{|c|}{ Increasing number of revertants/plate } \\
\hline & & & \multicolumn{2}{|c|}{ TA98 } & \multicolumn{3}{|c|}{ TA100 } \\
\hline & & & $\mathrm{BaP}$ & $\mathrm{AAF}$ & $\mathrm{BaP}$ & $\mathrm{AAF}$ & DMN \\
\hline \multirow[t]{20}{*}{ Rat } & \multirow[t]{5}{*}{ SD (male) } & control & 24 & 361 & 112 & 120 & 183 \\
\hline & & PCB & 125 & 728 & 518 & 427 & 616 \\
\hline & & $\mathrm{PB}$ & 43 & 595 & 123 & 247 & 185 \\
\hline & & $\operatorname{MC}(1) *$ & 37 & 407 & 219 & 255 & 158 \\
\hline & & $\mathrm{MC}(5)^{*}$ & 42 & 401 & 362 & 269 & 129 \\
\hline & \multirow[t]{5}{*}{$\mathrm{SD}$ (female) } & control & 18 & 109 & 64 & 74 & 77 \\
\hline & & PCB & 32 & 163 & 283 & 342 & 1347 \\
\hline & & $\mathrm{PB}$ & 22 & 79 & 130 & 131 & 143 \\
\hline & & $\operatorname{MC}(1)^{*}$ & 23 & 201 & 187 & 175 & 159 \\
\hline & & $\operatorname{MC}(5)^{*}$ & 21 & 166 & 206 & 134 & 87 \\
\hline & \multirow[t]{5}{*}{ Fischer } & control & 25 & 98 & 85 & 79 & 111 \\
\hline & & PCB & 30 & 350 & 260 & 167 & 727 \\
\hline & & $\mathrm{PB}$ & 13 & 80 & 64 & 61 & 87 \\
\hline & & MC (1)* & 22 & 124 & 112 & 84 & 83 \\
\hline & & $\mathrm{MC}(5)^{*}$ & 26 & 130 & 193 & 191 & 225 \\
\hline & \multirow[t]{5}{*}{ Wistar } & control & 40 & 332 & 122 & 149 & 115 \\
\hline & & $\mathrm{PCB}$ & 56 & 563 & 486 & 375 & 269 \\
\hline & & PB & 21 & 313 & 140 & 133 & 251 \\
\hline & & $\mathrm{MC}(1)^{*}$ & $57 * *$ & $437 * *$ & 272 & 177 & 167 \\
\hline & & $\mathrm{MC}(5)^{*}$ & $345 * *$ & $730 * *$ & 378 & 308 & 231 \\
\hline \multirow[t]{10}{*}{ Mouse } & \multirow[t]{5}{*}{ dd } & control & 27 & 245 & 108 & 164 & 245 \\
\hline & & PCB & 18 & 1335 & 198 & 586 & 846 \\
\hline & & $\mathrm{PB}$ & 14 & 462 & 128 & 207 & 182 \\
\hline & & MC (1)* & 24 & 920 & 518 & 609 & 311 \\
\hline & & $\mathrm{MC}(5)^{*}$ & 15 & 434 & 264 & 344 & 322 \\
\hline & \multirow[t]{5}{*}{ ICR } & control & 28 & 39 & 86 & 93 & 291 \\
\hline & & PCB & 24 & 334 & 147 & 263 & 523 \\
\hline & & $\mathrm{PB}$ & 21 & 140 & 91 & 115 & 323 \\
\hline & & $\mathrm{MC}(1)^{*}$ & 14 & 21 & 75 & 78 & 140 \\
\hline & & $\mathrm{MC}(5)^{*}$ & 27 & 78 & 108 & 97 & 138 \\
\hline \multirow[t]{7}{*}{ Guinea pig } & \multirow[t]{5}{*}{ Hartley } & control & 132 & 1723 & 558 & 95 & 260 \\
\hline & & PCB & 413 & 1773 & 751 & 720 & 753 \\
\hline & & PB & 109 & 1997 & 360 & 111 & 400 \\
\hline & & MC (1)* & 475 & 1555 & $523 * *$ & $271 * *$ & $359 * *$ \\
\hline & & $\mathrm{MC}(5)^{*}$ & 597 & 1718 & 544 & 542 & 692 \\
\hline & \multirow[t]{2}{*}{ hybrid } & control & 32 & 1483 & 166 & 602 & 138 \\
\hline & & PCB & 85 & 1894 & 352 & 266 & 1029 \\
\hline \multirow[t]{7}{*}{ Rabbit } & New & control & 31 & 879 & 231 & 515 & 176 \\
\hline & Zealand & PCB & 84 & 1642 & 648 & 335 & 273 \\
\hline & \multirow[t]{3}{*}{ White } & PB & 17 & 1603 & 150 & 691 & 782 \\
\hline & & $\operatorname{MC}(1)^{*}$ & 38 & 763 & 244 & 350 & 150 \\
\hline & & $\operatorname{MC}(5)^{*}$ & 108 & 1646 & 733 & 404 & 284 \\
\hline & Japanese & control & 21 & 77 & 135 & 113 & 136 \\
\hline & native & PCB & 42 & 1769 & 268 & 342 & 493 \\
\hline
\end{tabular}


Table 1. (continued)

\begin{tabular}{|c|c|c|c|c|c|c|c|}
\hline \multirow{3}{*}{$\begin{array}{l}\text { Animal } \\
\text { species }\end{array}$} & \multirow{3}{*}{ Strains } & \multirow{3}{*}{ Inducers } & \multicolumn{5}{|c|}{ Increasing number of revertants/plate } \\
\hline & & & \multicolumn{2}{|c|}{ TA98 } & \multicolumn{3}{|c|}{ TA100 } \\
\hline & & & $\mathrm{BaP}$ & AAF & Bap & $\mathrm{AAF}$ & $\mathrm{DMN}$ \\
\hline \multirow{7}{*}{ Hamster } & Golden & control & 19 & 1327 & 195 & 904 & 929 \\
\hline & & $\mathrm{PCB}$ & 71 & 1365 & 301 & 319 & 1327 \\
\hline & & $\mathrm{PB}$ & 31 & 1608 & 177 & 710 & 1157 \\
\hline & & $\operatorname{MC}(1)^{*}$ & 104 & 1598 & $838 * *$ & $282^{* *}$ & $984 * *$ \\
\hline & & $\operatorname{MC}(5)^{*}$ & 54 & 1775 & $361 * *$ & $491 * *$ & $1925 * *$ \\
\hline & Chinese & control & 42 & 2000 & 274 & 587 & 613 \\
\hline & & PCB & 35 & 2022 & 166 & 127 & 1168 \\
\hline
\end{tabular}

* $[\mathrm{MC}(1)]$ and $[\mathrm{MC}(5)]$ indicate 1 and 5 day samples after MC treatment, respectively.

** These samples gave high background reversion levels. Dosage levels of mutagens were $10 \mu \mathrm{g} /$ plate for BaP, $80 \mu \mathrm{g} /$ plate for AAF and $3000 \mu \mathrm{g} /$ plate for DMN.

reverse mutation in TA98 and TA100, followed by $\mathrm{MC}$ and $\mathrm{PB}$. PB-treatment was effective only on a limited part of AAF-induced mutagenesis. MC-treatment was effective on $\mathrm{BaP}$ and AAF-mutagenesis, but in some cases it gave high background level of mutants, disturbing to accurately count the actual reversion by the mutagens, probably because of contaminated mutagen(s) which might be derived from pre-treated MC. The 5th day S-9 fractions $[M C(5)]$ were more effective than those of the first day $[\mathrm{MC}(1)]$ in all species except dd strain mouse.

Among 51 species-inducer combinations including the control (non-treated), several of the highly efficient S-9 fractions are listed:

1) Bap-induced mutation

TA98;

PCB-, MC(1)- and MC(5)- Hartley guinea pig

TA100

PCB- and MC(5)- New Zealand White rabbit

PCB- and MC(5)- Hartley guinea pig

PCB- and $\mathrm{MC}(5)$ - Wister and SD rat

$\mathrm{MC}(1)$ - dd mouse

2) AAF-induced mutation

TA98;

$\mathrm{PB}, \mathrm{PCB}, \mathrm{MC}(5)$ - and control- Hartley guinea pig

PCB- hybrid guinea pig

MC(5)- New Zealand White rabbit

MC(5)- Japanese native rabbit

MC(5)- Golden hamster

PCB- and control- Chinese hamster
TA100;

PB- and control- Golden hamster

PCB- and MC(5)- Hartley guinea pig

PB- and control- New Zealand White rabbit

control- hybrid guinea pig

control- Chinese hamster

3) DMN- induced mutation

\section{TA100;}

PCB-, PB- and control- Golden hamster

PCB- Chinese hamster

PCB- SD rat (female)

PCB- hybrid and Hartley guinea pig

Thus, depending on the combination of mutagen tested and bacterial strain used, the best S-9 fraction (or more exactly mammalinducer combination) was different. Moreover, as shown in Fig. 2, the optimal concentration of mutagen giving rise to maximum revertant colonies was variable with S-9 fraction used.

Because of the above reasons, it is not easy to specify one mammalian species-inducer combination as the best S-9 fraction to be applicable to any mutagen to be tested. However, since the PCB-induced Hartley guinea pig S-9 was generally more effective in increasing the revertant colonies of both S. typhimurium TA98 and TA100 by 3 different types of mutagens, the S-9 fraction can be proposed to be even better than PCB-induced SD rat which is commonly used. MC-induced Hartley guinea pig liver preparation $[\mathrm{MC}(5)]$ can be also used instead of PCB-induced SD rat, as the former gave as many mutant colonies as the latter. Moreover, DMN induced mutants of TA100 
were remarkably more increased by S-9 fractions from PCB-treated both hamster strains than by that of Hartley guinea pig.

Guinea pigs have not been considered so far a species suitable for carcinogenicity study, and rats and mice are the preferred experimental animals. So, for S-9 fraction in the Ames test detecting carcinogens as mutagens, the rat preparation might be better for the coherence purpose. Actually, in one of their recent report Ames et al ${ }^{8}{ }^{8}$ stated that approximately $90 \%$ of various types of chemical carcinogens were detected as mutagens by $S$. typhimurium strains combined with rat S-9 fraction. Moreover, for example, guinea pigs were reportedly not susceptible to carcinogenic potential of AAF due to the lack of AAF N-hydroxylase activity. ${ }^{9}$ ) However, since rat hepatic S-9 fraction is not intrincically the best drug mutabolizing enzyme source, and that metabolic pathways in a mammalian species are one of the prerequisites for a certain type of chemicals to be carcinogen, S-9 fraction prepared from their species of mammals than rats including guinea pigs might be used to enable Ames and similar carcinogen-screening tests to be more sensitive and more reliable.

\section{要約}

突然変異性発ガン性化合物のスクリーニング方法とし て一般的に用いられている Ames の方法について，そ の in vitro 代謝系の改良をするため， $\mathrm{PCB}$,フェノバル ビタールおよび 3-メチルコラントレンのそれぞれを投 与し薬物代謝系を誘導したラット，マウス，モルモット， 八ムスター，およびウサギよりの肝臓 S-9画分を用い,
サルモネラ菌 TA98 株，TA100 株の突然变異体出現数 の変化を調べた。

5 動物種 12 系統のなかで, $\mathrm{PCB}$ 処理ハートレー采 モルモットより得た S-9 画分は，3 種の異なった化合物 (ベンツ (a)ピレン，2-アセチルアミノフルオレン，ジメ チルニトロソアミン）の变異性検出において，通常用い られている PCB 処理 SD ラットよりすぐれていた。 ま た 3-メチルコラントレン処理モルモット（ハートレー 系）は，PCB 投与 SD ラットとほぼ同等であることが 認められ，八ムスターの S-9 は, DMN の突然変異の 検出に有効であった。

一方，ウィスター系执よびフィッシャー系ラット， ICR 系， dd 系マウス，ウサギ，などは，SD 系と比較 してとくにすぐれているとはみなせない.

\section{REFERENCES}

1) B. N. Ames, W. E. Durston, E. Yamasaki \& F. D. Lee: Proc. Nat. Acad. Sci. USA 70, 2281 (1973)

2) B. N. Ames, J. McCann \& E. Yamasaki: Mutation Res. 31, 347 (1975)

3) F. Gletten, U. Weekers \& D. Brusick: Mutation Res. 28, 113 (1975)

4) U. Weekers \& D. Brusick: Mutation Res. 31, 175 (1975)

5) J. McCann, N. E. Spingarn, J. Kobori \& B. N. Ames: Proc. Nat. Acad. Sci. USA 72, 979 (1975)

6) H. Suzuki \& J. Miyamoto: J. Pesticide Sci. 1, 253 (1976)

7) T. Omura \& R. Sato: J. Biol. Chem. 239, 2270 (1964)

8) J. McCann, E. Choi, E. Yamasaki \& B. N. Ames: Proc. Nat. Acad. Sci. USA 72, 5135 (1975)

9) E. C. Miller, J. A. Millar \& M. Enomoto: Cancer Res. 24, 2018 (1964) 